\title{
MEMAKNAI TERMINOLOGI JIHAD DALAM AL-QUR'AN DAN HADIS
}

\author{
A.Rahman Ritonga \\ Fakultas Ushuluddin Adab dan Dakwah IAIN Bukittinggi \\ e-mail:rahman_ritonga@yahoo.co.id \\ DOI: http:/ / dx.doi.org/10.30983/islam_realitas.v2i1.105
}

Diterima: 25 Maret 2016 $\quad$ Direvisi:3 April $2016 \quad$ Diterbitkan: 20 Juni 2016

\begin{abstract}
The term of jibad in al-Qur'an is used for two things. The first term is the general definition which means shed the all abilities for struggle to uphold the truth and to fight against evil in order to obtain the God's blessing. In this sense, jihad becomes an individual duty of every Muslim based on their capabilities, and the implementation of jihad is based on the Islamic law. The second term is the specific definition which means mobilize all capabilities against enemies of Islam. In this sense, jihad should be based on the decision of the leader and implemented in an organized manner, in order not to get out of prescribed ethics of jibad. Jihad carried out as the last alternative to defend community and religion, conducted in defensive rather than offensive. Jihad in the form of terrorism, suicide and the like are $n$ admitted as prescribed jibad. The verses of the Qur'an and hadith talk a lot about the issue of jibad as evidence of the important role of jibad in establishing the truth on this earth. Jihad in accordance to Qur'an and the hadith is interpreted as a maximum effort to establish the truth of God.
\end{abstract}

Keywords: Jihad, Terorism.

\section{Abstrak}

Istilah jihad di al-Qur`an digunakan untuk dua hal. Istilah pertama adalah definisi umum yang berarti menumpahkan semua kemampuan untuk perjuangan menegakkan kebenaran dan melawan kejahatan untuk mendapatkan berkat Tuhan. Dalam hal ini, jihad menjadi kewajiban individu dari setiap Muslim sesuai dengan kemampuan mereka, dan pelaksanaan jihad adalah sesuai dengan hukum Islam. Istilah kedua adalah definisi khusus yang berarti untuk memobilisasi semua kemampuan melawan musuh-musuh Islam. Dalam hal ini, jihad harus didasarkan pada keputusan pemimpin dan dilaksanakan secara terorganisir, agar tidak keluar dari etika ditentukan dari jihad. Jihad dilakukan sebagai alternatif terakhir untuk membela masyarakat dan agama, yang dilakukan secara defensif daripada ofensif. Jihad dalam bentuk terorisme, bunuh diri dan sejenisnya tidak diterima sebagai jihad yang ditentukan. Ayat al-Qur'an dan hadis Rasulullah banyak membicarakan persoalan jihad sebagai bukti pentingnya peran jihad dalam menegakkan kebenaran di bumi ini. Jihad menurut al-Qur'an dan hadis dimaknai sebagai upaya maksimal untuk menegakkan kebenaran Allah.

Kata Kunci: Jihad, Terorisme.

\section{Latar Belakang}

Sejak tumbuh dan berkembangnya Islam di Mekkah dan di Madinah, terminologi jihad sudah diperkenalkan oleh al-Qur'an dan hadis, oleh karena itu tidak heran jika istilah jihad telah lama dikenal oleh umat Islam. Al-Qur`an dan hadis pada umumnya mengandung anjuran dan informasi tentang keutamaan-keutamaan berjihad. Ahli tafsir kemudian, atas dasar kedua sumber ajaran itu, merekomendasikan kewajiban berjihad bagi setiap individu Muslim untuk melestarikan yang hak dan melawan segala kebatilan.

Dalam sejarah perjuangan menegakkan kebenaran, jihad sering dipahami sebagai media perlawanan terhadap musuh-musuh Islam sehingga menurut Abdillah implementasi jihad pun sering berbentuk kekerasan, anarkis dan teroris. Identitas Islam sebagai agama yang 
membawa rahmat, keselamatan dan kedamaian, bukan hanya bagi umat Islam, tetapi juga bagi penganut agama lain telah ternodai oleh aksi kekerasan yang dilakukan sekelompok umat Islam radikal yang mengatasnamakan "jïhad fi sabilillah." 1 Kemudian, aksi-aksi tersebut oleh Barat yang alergi terhadap perkembangan Islam dimanfaatkan untuk membangun isu dan propoganda yang merugikan umat Islam secara umum. Propaganda mereka ternyata berhasil dengan banyaknya dukungan mendeskriditkan Islam dengan nama teroris, al-Qaeda, ISIS, dan radikal.

Bahwa agama merupakan suatu keyakinan bagi manusia dan kebutuhan yang paling asasi dalam hidupnya. Menurut kodratnya, manusia dalam hidupnya selalui mengakui adanya kekuatan yang maha dahsyat di luar dirinya. Ia selalu merasakan di luar dirinya ada kekuatan yang tak mungkin ditandingi oleh kekuatan apapun di alam ini. Keyakinan seperti inilah yang biasa disebut dengan beragama ${ }^{2}$. Objek keyakinan terhadap kekuatan yang ada di luar dirinya ditemukan oleh akal manusia. Karena kemampuan akal manusia itu berbeda, maka terjadilah perbedaan agama, meskipun tujuannya sama yakni mencari kedamaian dan kebahagian di dunia dan di akhirat.

Oleh sebab itu, manusia membutuhkan agama, karena agama itu dapat memberi petunjuk untuk keselamatan dan kedamaian. Dengan agama, manusia mendapatkan wadah pencerahan dan pencurahan hatinya pada ketika gundah gulana. Dengan agama pula manusia mendapatkan nilai-nilai moral universal yang tidak mungkin didapatkan oleh kekuatan akal semata. Oleh karena itu agama

1 Abdillah, Junaidi, "Radikalisme Agama: Dekonstruksi Tafsir Ayat-Ayat "Kekerasan" dalam AlQur'an", Kalam, Vol. 8, No. 2, 2014, h. 281-300.

${ }^{2}$ Tim Penyusun Puslit IAIN Jakarta, Pendidikan Kewarnegaraan, Demokrasi, HAM dan Masyarakat Madani (Jakarta: IAIN Syahid Press: 2000), h. 123. dan beragama merupakan hak asasi bagi setiap manusia. Setiap orang bersedia melakukan apa saja demi keyakinan agama, dan tidak ada penganut agama yang rela bila agamanya dihina dan direndahkan oleh penganut agama lain.

Secara normatif-doktriner, dalam penelitian Hanafi, agama selalu mengajarkan kebaikan, cinta kasih, dan kedamaian. Namun kenyataan sosiologis sering mempertontonkan sebaliknya dimana agama menjadi ajang konflik yang tak kunjung reda ${ }^{3}$. Upaya untuk menciptakan kerukunan umat beragama sebenarnya telah lama dibina. Sejak tahun 1967 pemerintah telah berulangkali memfasilitasi dialog antar umat beragama untuk mencari titik temu sebagai markas kebersamaan. ${ }^{4}$ Namun buahnya selalu mentah, dimana SARA masih membuat bulu kuduk merinding dan menakutkan sebagaimana selama ini disikapi oleh umat manusia yang hidup di negara pluralis. Itulah sebabnya di Indonesia yang dihuni oleh umat beda agama, suku, ras, etnis, dan golongan selalu berusaha menciptakan iklim kebersamaan dalam keberagaman. ${ }^{5}$

Indonesia dikenal sebagai salah satu negara di dunia yang memiliki banyak suku bangsa, bahasa, dan budaya. Oleh karena itu Indonesia dapat dikatakan sebagai negara yang rawan konflik. ${ }^{6} \mathrm{Di}$ Indonesia sering terjadi konflik yang dipicu oleh isu SARA, perkelahian

${ }^{3}$ Muhammad Muchlis Hanafi, "Problematika Terjemahan Al-Qur'an Studi pada Beberapa Penerbitan Al-Qur'an dan Kasus Kontemporer", Subuf Jurnal Pengkajian Al-Qur'an dan Budaya, Vol. 4, No. 2, 2011, h. 169-195. Bandingkan dengan Zulfan Taufik, "Humanisme dan Ambivalensi Agama: Sinergi Pluralisme dan HAM dalam Menjaga Nilai Kemanusiaan", Titik Temu: Jurnal Dialog Peradaban, Vol. 7, No. 2, 2015

${ }^{4}$ Imam Suprayogo, dalam buku Islam dan Hegemoni Sosial (Jakarta: Direktorat Perguruan Tinggi Agama Islam Departemen Agama RI, 2001), hal. 23.

${ }^{5}$ A. Qadri Azizy, Pendidikan (Agama) Untuk Membangun Etika Sosial (Semarang: Aneka Ilmu, 2002), h.119.

${ }^{6}$ Tim Penyusun Puslit IAIN Jakarta, Pendidikan Kewarganegaraan, Demokrasi, HAM dan Masyarakat Madani,..., h. 11. 
antardaerah, suku, agama, dan bahkan antarsekte agama. ${ }^{7}$ Isu SARA sering digunakan oleh orang-orang yang tidak ingin Indonesia damai untuk menebar benih kebencian. Mereka inilah sering yang disebut "provokator". Sampai saat ini provokator masih bergentayangan mengintai keadaan yang berpotensi konflik dengan menjual isu SARA.

Indonesia tidak hanya dikenal multi kultural, tapi juga multi agama. Sejak berabadabad negeri ini mengenal lima agama besar dunia: Hindu Budha, Kristen, Katolik, dan Islam. Yang pertama datang ke negeri ini adalah Hindu dan Budha, kemudian disusul oleh Islam, dan terakhir Kristen dan Katolik. Pada awalnya hubungan antara komunitas yang berbeda agama tersebut berjalan secara harmonis, tidak ada persinggungan apalagi jihad dalam arti anarkis antarumat beragama. Akan tetapi pada abad kedua puluh ini (tepatnya sejak tahun 1960-an) terjadi perubahan. Hubungan antar komunitas beda agama mulai kurang harmonis terutama antara Islam dan Kristen (Protestan dan Katolik). ${ }^{8}$ Hal ini menurut Shidiq disebabkan karena kedua agama ini adalah agama misi, dimana umatnya diajak berdakwah ke agama Tuhannya sebagai ibadah yang menjanjikan pahala dan surga?.

Masyarakat Indonesia yang majemuk dan memiliki keberagaman agama, ternyata sangat rentan, rawan dan berpotensi menmibulkan kesalah-pahaman, perbedaan pandangan, dan prasangka negatif yang menjurus ke arah terjadinya konflik. ${ }^{10}$ Banyak kekerasan yang

${ }^{7}$ Leo Suryadinata, Etnis dan Pembangunan Bangsa (Jakarta: LP3ES, 1999), h. 152.

${ }^{8}$ Harun Nasution, Islam Rasional, Gagasan dan Pemikiran (Bandung: Mizan, 1998), h. 262.

${ }^{9}$ Shidiq, Ghofar, "Teori Maqashid Al-Syari'ah dalam Hukum Islam", Majalah Imiah Sultan Agung, 44.11.8, 2018, h 117-130

${ }^{10}$ Badan Litbang dan Diklat Kementerian Agama RI, Merajut Kerukunan Umat Beragama Melalui Dialog Pengembangan Wawasan Multi Kultural ( Jakarta: t.p., 2008), Cet. 2, h. 118. terjadi di negara ini yang melibatkan isu agama sebagai faktor penyebabnya. Kasus Ambon misalnya, ${ }^{11}$ sering kali diisukan sebagai pertikaian antara komunitas yang berbeda agama. Aksi-aksi kekerasan itu oleh sebagian penganut agama diisukan bermotif agama, sehingga riaknya mempengaruhi hubungan antarkomunitas beda agama di negara ini. Semua tragedi itu mendorong terjadinya kekerasan yang mengunakan label jibad fi sabilillah. Berdasarkan fenomena penafsiran dan pendefinisian makna jihad tersebut, tulisan ini akan menjelaskan tentang makna dan terminologi jihad berdasarkan al-Qur'an dan Hadis.

\section{Makna Jihad dalam al-Qur'an dan Hadis}

Kata jihad berasal dari kosa kata al-jahd dan dari sini muncul berbagai bentuk kata, seperti jahada, yujabidu, jabid, mujabadah, jihad, dan jubd. Kata jihad dengan segala bentuknya ditemukan di dalam al-Qur an sebanyak 39 kali yang tersebar di 18 surat dan 28 ayat. Ada yang ditemukan pada ayat yang turun sebelum Nabi hijrah ke Madinah dan ada yang ditemukan pada ayat yang turun sesudah hijrahnya. Berikut akan dijelaskan makna dan penggunaan kata jihad tersebut pada masingmasing surat dan ayat yang diperjelas oleh hadis-hadis Rasulullah saw.

Pertama, pada surat al-Baqarah, kata itu ditemukan dalam bentuk kata kerja masa lalu (madhi) sebanyak 1 (satu) kali yang tertulis pada ayat 218. Di sini jihad diartikan dengan usaha keras dengan mengerahkan segala kemampuan yang dimiliki untuk mendapatkan ridha Allah. Termasuk di dalamnya melindungi orang-orang mukmin dari gangguan orang kafir.

Makna jihad seperti yang di antar oleh ayat di atas juga disampaikan oleh Nabi dengan hadisnya dari Abu Hurairah ra., Rasul berkata:

11 Tim Penyusun PUSLIT IAIN Jakarta, Pendidikan Kewarganegaraan, Demokrasi, HAM dan Masyarakat Madani,..., h. 13. 
"Perumpamaan orang yang berjihad fi sabilillah itu ialah seperti orang yang berpuasa, dan ibadah lain dengan sungguh-sungguh, yang taat dalam mengamalkan ayat-ayat Allah, tidak lalai dari shalat dan puasanya (Muttafaq 'alaib). Dalam riwayat Imam Bukhari disebutkan: Ada seorang lelaki berkata: "Ya Rasulullah, tunjukkanlah kepada saya akan sesuatu amalan yang pahalanya menyamai jihad!" Beliau bersabda: "Adakah engkau kuat kalau sekiranya orang yang berjihad itu keluar lalu engkau masuk dalam masjidmu, kemudian engkau terus mendirikan ibadah dan tidak lalai sedikit pun, juga dengan berpuasa dan tidak pernah berbuka sampai orang yang berjihad itu kembali?" Orang itu lalu berkata: "Siapakah yang kuat melakukan seperti itu." (HR. AlBukhari). Artinya menurut hadis di atas, kata jihad digunakan untuk arti beramal ibadah dengan cara serius dan sungguh-sugguh dan Allah menjanjikan pahala untuknya seperti pahala orang yang berjihad melawan orang musyrik.

Kedua, dalam surat Ali Imran, kata jihad disebut 1 (satu) kali dalam bentuk kata kerja madhi, tepatnya pada ayat 142 yang turun setelah Rasulullah hijrah ke Madinah. Di sini jihad menurut Fazlurrahman dalam Syukri diartikan dengan perang melawan orang kafir. Ulama menjadikan ayat ini sebagai dalil bahwa jihad melawan orang kapir adalah fardu kifayah $^{12}$. Al-Maraghi melalui ayat ini membagi jihad itu kepada: 1) memerangi (harab) orang kafir yang ingin menghancurkan agama dan memadamkan kalimat Allah di bumi ini. 2) membangun kemaslahatan umat dengan harta kekayaan. 3) melawan hawa nafsu dengan kesabaran dan pengendalian diri dan 4) menegakkan kebenaran dan melawan semua kebatilan.

\footnotetext{
${ }^{12}$ Syukri, Ahmad, "Metodologi Tafsir al-Qur'an Kontemporer dalam Pemikiran Fazlur Rahman", Kontekstualita, Vol. 20, No. 1, 2005, h. 15.
}

Abu Zar ra. bertanya: "Ya Rasulullah, amalan apakah yang lebih utama?" Beliau saw. menjawab: "Yaitu beriman kepada Allah dan berjihad fi sabilillab." (Muttafaq 'alaih) Anas ra. Menceritakan, Rasulullah saw. bersabda: "Sesungguhnya sekali berangkat untuk berperang $f i$ sabilillah, di waktu pagi atau pun sore itu adalah lebih baik nilainya daripada dunia dan segala isinya" (HR. Muttafaq 'alaih). Isi hadis ini sejalan dengan yang diterangkan dalam hadis Sahl bin Sa'ad yang diriwayatkan oleh al-Bukhari dan Muslim, dimana kata jihad diartikan untuk berperang melawan orangorang kafir yang memeranginya.

Ketiga, dalam surat al-Nisa' kata ini ditemukan dalam bentuk kata benda (isim) yang disebut 3 (tiga) kali, semuanya pada ayat 95 yang tergolong ayat Madaniyah. Di sini kata jihad dimaknai sebagai sifat kerelaan mengorbankan harta kekayaan untuk keperluan biaya operasional, peralatan dan fasilitas jihad yang dibutuhkan serta kerelaan mengorbankan jiwa raganya dengan keikutsertaan, pikiran dan semangat untuk menegakkan kebenaran dan melawan kebatilan.

Makna jihad dalam ayat ini dipertegas pula dengan hadis dari Abu Yahya ra. yang mengatakan bahwa Rasulullah bersabda: "Barangsiapa yang menafkahkan sesuatu nafkah untuk peperangan fi sabilillah, maka baginya pahala sebanyak tujuh ratus kali lipatnya." (HR. Imam Muslim). Tidak berbeda dengan hadis yang disampaikan oleh Zaid bin Khalid ra. bahwa Rasulullah saw. bersabda: "Barangsiapa yang memberikan persiapan seperti kendaraan, bekal, senjata, dan lain-lain kepada seorang yang melakukan peperangan di jalan Allah, maka ia dinilai ikut berperang. (HR. Muttafaq 'alaih)

Keempat, dalam surat al-Maidah, kata jihad diulang sebanyak 3 (tiga) kali dalam bentuk yang berbeda, yaitu pada ayat 35 yang turun setelah hijrah, disebut dalam bentuk kata perintah. Menurut Quraish Shihab dalam 
Wartini, kata jihad di sini diartikan sebagai upaya keras dengan segala kemampuan menegakkan ajaran Allah dengan cara mengerjakan semua perintah dan meninggalkan semua larangan Allah ${ }^{13}$. Sedangkan pada ayat 53 disebut dalam bentuk kata benda yang dikaitkan dengan kata sumpah yang diucapkan oleh orang-orang munafik bukti kesungguhan menyertai orang mukmin, meskipun kemudian sumpah mereka itu mendapat cemoohan dari orang-orang mukmin, karena mereka berbohong dalam sumpahnya. Dengan demikian, kata jihad di sini diartikan sebagai suatu kesungguhan hati untuk melakukan atau menepati janji. Sementara pada ayat 54 yang ditulis dalam bentuk kata kerja masa kini (mudhari) dikaitkan dengan banyaknya orang yang murtad, kemudian oleh Allah dijanjikan kepada mereka akan muncul sekelompok orang yang lemah lembut terhadap orang mukmin dan tegas terhadap orang kafir yang berjihad di jalan Allah tanpa merasa takut terhadap tantangan dan cemoohan. Atas dasar itu, kata jihad di sini diartikan sebagai upaya serius dalam menegakkan ajaran Islam dan setia pada janji serta tabah dalam menghadapi kesulitan.

Ibnu Qatadah ra. menceritakan bahwa Rasulullah saw. berdiri di hadapan orang banyak lalu mengingatkan bahwa jihad $f i$ sabilillah dan keimanan kepada Allah itu adalah amal yang paling utama, kesalahan-kesalahan dan dosanya dihapus. Dan jika terbunuh dalam peperangan sedang dia sabar menghadapi kesulitan dan tidak pernah berniat untuk mundur meninggalkan medan peperangan semata mengharap redha Allah (HR. Muslim).

Kelima, dalam surat al-An am, kata ini disebut 1 (satu) kali pada ayat 109 yang tergolong ayat Makkiyyah. Kata jihad dalam

${ }^{13}$ Wartini, Atik. "Corak Penafsiran M. Quraish Shihab dalam Tafsir al-Misbah", Hunafa: Jurnal Studia Islamika, Vol. 11, No. 1, 2014, h. 109-126. bentuk kata benda dikaitkan dengan kata sumpah yang berindikasi kepada makna kesugguhan dengan memanfaatkan kemampuan untuk melakukan sesuatu atau mempertahankan prinsip. Makna jihad seperti ini juga ditemukan dalam hadis yang disampaikan oleh Sufyan bin Abdillah ra. berkata kepada Rasulullah, "Wabai Rasulullah, katakanlah kepadaku perkataan tentang islam yang tidak akan aku tanyakan kepada selain engkau!" Beliau bersabda, "Katakanlah, Amantu Billah (Aku beriman kepada Allab), kemudian istiqamalah'." (Diriwayatkan oleh Imam Muslim). Aisyah RA. menceritakan: Nabi pernah ditanya: "Manakah amal yang paling dicintai Allah? Beliau bersabda: "Yang dilakukan secara terus menerus meskipun sedikit. Beliau bersabda lagi:"Dan lakukanlah amal-amal itu, sekadar kalian sanggup melakukannya." (HR. al- Bukhari).

Keenam, dalam surat al-Anfal, yang tergolong surat Makkiyyah, terulang 3 (tiga) kali dalam bentuk kata kerja madhi pada ayat 72, 74, dan 75. Ayat-ayat ini memberi indikasi bahwa kata jihad digunakan untuk arti kerelaan mengorbankan harta kekayaan dan jiwa raga dalam mempertahankan agama tauhid. Di sini jihad berkaitan dengan peristiwa hijrahnya Rasul dan sahabatnya ke Madinah yang konsekwensinya kehilangan harta, rumah, usaha di Mekkah yang belum tentu kembali ke tangan mereka. Hijrah juga menuntut kesediaan mengorbankan tenaga, pikiran perasaan bahkan jiwa menantang perjalanan jauh dan bahaya yang akan dihadapi. Dalam Mustaqim, jika jihad dimaknai dengan kontak senjata, maka harta digunakan untuk membeli pedang, kuda, kesehatan, dan biaya operasional lainnya ${ }^{14}$.

${ }^{14}$ Mustaqim, Abdul, "Deradikalisasi Penafsiran Al-Qur'an dalam Konteks Keindonesiaan yang Multikultur", Subuf Jurnal Pengkajian Al-Qur'an dan Budaya, Vol. 6, No. 2, 2013, h. 149-167. 
Nabi Muhammad saw. pernah bersabda seperti yang bersumber dari Umar bin Khattab yang mendengar langsung dari Nabi. Segala amal itu tergantung niatnya, dan setiap orang banya mendapatkan sesuai niatnya. Maka barang siapa yang bijrabnya kepada Allah dan Rasul-Nya, maka bijrabnya itu kepada Allah dan Rasul-Nya. Barang siapa yang bijrabnya itu Karena kesenangan dunia atau karena seorang wanita yang akan dikawininya, maka bijrabnya itu kepada apa yang ditujunya." (HR. al-Bukhari). Hadis yang disampaikan dari Anas menerangkan perintah Rasulullah supaya berjihad melawan orang musyrik dengan harta, jiwa dan lidah (HR. Ahmad dan al-Nasa i). Dalam hadis ini ada tiga hal yang dapat digunakan untuk jihad yaitu harta kekayaan, jiwa dan lidah (dakwah dengan argumentasi alQur'an).

Ketujuh, dalam surat al-Taubah, kata jihad dengan berbagai bentuknya disebut 8 (delapan) kali. Di dalam ayat 16 tertulis dalam bentuk kata kerja masa lalu yang diturunkan untuk mendorong orang mukmin membersikan negeri Arab dari kemusyrikan dan kemunafikan. Pada ayat 19 yang ditulis dalam bentuk kata kerja, jihad merupakan implementasi dari keimanan yang mengambil bentuk amal-amal saleh seperti memakmurkan mesjid, mendirikan shalat, membayarkan zakat dan dan lain-lain. Adapun kata jihad pada ayat 20 berkonotasi kepada kesediaan mendermakan harta kekayaan dan mengorbankan jiwa dalam bentuk pemikiran, perasaan dan bahkan jika perlu mengorbankan jiwa dalam arti yang sebenarnya untuk mendapatkan derajat yang tinggi di sisi-Nya. Pada ayat 25 dalam bentuk kata benda diguanakan untuk arti hijrah meninggalkan kota Mekkah dengan segala pasilitas dan kenangannya. Kata jihad dalam bentuk perintah pada ayat 41 digunakan untuk arti perjuangan melawan orang kafir yang memerangi umat Islam. Menurut al-Zuhry, ayat ini turun berkenaan dengan keinginan kuat
Sayyid al-Musayyib untuk ikut ke medan pertempuran padahal matanya uzur sebelah. Ketika orang mencegahnya untuk tidak ikut, ia berkata "Allah telah menyuruh aku ikut berperang". Dengan membaca ayat 41 ini Abu Thalhah memerintahkan anak-anaknya untuk mempersiapkan peralatan perangnya.

Sementara pada ayat 44, kata jihad dalam bentuk kata kerja masa kini juga digunakan untuk arti mengerahkan kemampuan untuk melawan orang-orang kafir. Karena ayat ini berkaitan dengan keengganan orang munafik berjihad bersama Rasul melawan orang kafir, maka makna jihad di sini adalah berperang melawan kaum yang memusuhi Rasulullah. Pada ayat 73 kata jihad berkaitan dengan perintah Allah agar Rasulullah berjihad melawan orang kafir dan bersikaf tegas kepada mereka, artinya jihad digunakan untuk makna perang melawan orang kafir. Dalam ayat 79 dengan bentuk kata benda, kata jihad digunakan untuk arti kemampuan atau kesanggupan. Selanjutnya kata jihad dalam bentuk kata kerja masa kini yang ditemukan pada ayat 81 digunakan untuk makna berperang melawan musuh. Menurut Nadia, informasi ini mengindikasikan jihad sebagai peperangan melawanu orang-orang kafir ${ }^{15}$. Terakhir pada surat ini kata jihad ditulis dalam bentuk kata kerja madhi pada ayat 88. Di sini kata jihad memiliki arti berperang melawan orang kafir dengan mengerahkan harta dan jiwa. Karena pada ayat sebelumnya diinformasikan tentang ketidakikutan anakanak, wanita, orang sakit, orang tua dan orang uzur lainnya ke medan peperangan, sedang Rasul bersama orang mukmin ikut berjihad dengan harta dan jiwa. Maka jihad di sini dapat diartikan berperang melawan orang-orang kafir.

${ }^{15}$ Nadia, Zunly, "Akar-Akar Radikalisme Islam dalam Tafsir fi Zilal Al-Qur'an Karya Sayyid Qutb." Mukaddimah: Jurnal Studi Islam, Vol. 18, No. 2, 2012, h. 56. 
Akhirnya kata jihad yang terdapat pada surat al-Taubah ini dipahami kepada dua makna, yaitu makna menegakkan kebenaran dan membasmi kebatilan serta melaksanakan amal-amal ibadah yang bermanfaat untuk dir sendiri dan orang lain. Kedua makna jihad untuk berperang secara fisik melawan orang kafir.

Kata jihad untuk kedua makna itu dapat dipertegas oleh Rasulullah lewat hadisnya yang disampaikan oleh Abu Hurairah ra. yang menceritakan bahwa Rasulullah bersabda: "Allah memberikan jaminan kepada orang yang keluar untuk berjihad fi sabilillah, dia keluar semata untuk berjihad dalam agamaKu, beriman kepadaKu, mempercayai RasulrasulKu, maka Allah menjamin memasukkannya dalam syurga. (HR. Imam Muslim dan Imam Bukhari). Pada hadis lain Abu Hurairah ra. berkata bahwa Rasulullah saw. mengatakan: "Di antara kehidupan yang terbaik bagi manusia ialah seorang yang memegang kendali kudanya untuk melakukan peperangan $f i$ sabilillah, ia terbang di atas punggungnya. Setiap kali ia mendengar suara gemuruh di medan peperangan, ia segera pergi ke sana untuk mencari supaya terbunuh di medan peperangan itu, maka ia dalam kebaikan." (HR. Muslim).

Abu Umamah menceritakan bahwa Rasulullah berabda: "Sedekah yang lebih utama ialah memberikan naungan kemah untuk peperangan fi sabilillah, memberikan pelayanan kepada orang yang berperang dan memberikan unta betina yang cukup dewasa untuk bertemu dengan unta jantan guna kepentingan peperangan. (HR. Imam Tirmidzi).

Kedepalan, dalam surat al-Nabl, kata jihad ditemukan 2 (dua) kali, satu pada ayat 38 dalam bentuk kata benda (isim) dikaitkan dengan kata sumpah yang diucapkan orang-orang kafir yang meyakini bahwa Allah tidak akan menghidupkan orang mati di akhirat. Dengan konteks ini maka kata jihad dimaksud digunakan untuk arti kesungguhan dalam ucapannya. Sedangkan pada ayat 110 yang ditulis dalam bentuk kata kerja masa lalu, diartikan dengan meninggalkan Mekkah menuju Madinah dengan segala konsekwensinya. Abdullah bin Umar menerangkan bahwa Rasulullah berkata "Hijrah meninggalkean segala yang dibencii Allah menuju yang dicintai-NYA (HR. Al-Bukhari).

Kesembilan, dalam surat al-Nur, kata jihad ditemukan 1 (satu) kali dalam bentuk kata benda pada ayat 53 yang turun setelah hijrah Rasulullah ke Madinah. Dalam Bakri, kata itu di sini dikaitkan dengan kata sumpah yang ducapkan orang-orang munafik untuk meyakinkan keikutsertaan mereka berperang jika disuruh. Konteks ini memberi petunjuk bahwa jihad digunakan untuk makna kesungguhan seperti yang sudah dijelaskan sebelumnya ${ }^{16}$.

Kesepuluh, dalam surat al-Furqan, kata jihad terdapat 1 (satu) kali pada ayat 52 dalam bentuk perintah. Kata jihad pada ayat ini digunakan untuk berijhad dengan al-Qur`an melawan orang-orang kafir dengan memperbaiki akidah dan akhlak. al-Qur'an adalah sumber utama informasi tentang Islam yang dapat diterima oleh manusia berakal. Perang menghadapi orang kafir dengan dakwah atau media imformasi dapat mempengaruhi sikap musuh menjadi lebih lembut. Imformasi al-Qur an sebagai alat perang lebih ampuh dan tajam dari mata pedang, apalagi ayat ini turun di Mekkah yang saat itu pedang umat Islam masih tumpul untuk perang terbuka. Perintah ini mengindikasikan makna jihad untuk dakwah. Atau peperangan dengan menggunakan AlQuran sebagai alat dan motivator bagi tegaknya ajaran Allah di bumi ini.

${ }^{16}$ Bakri, Syamsul, "Islam dan Wacana Radikalisme Agama Kontemporer", Jurnal Dinika, Vol. 3, No. 1, 2004, h. 1-8. 
Pengertian jihad menurut Yuslem seperti pada surat ini juga pernah disebut oleh Rasulullah melalui hadis yang dinukil Anas menerangkan perintah Rasulullah supaya berjihad melawan orang musyrik dengan harta, jiwa, dan lidah (HR. Ahmad dan al-Nasa i). Para ahli hadis mensyarah kata lidah itu dengan berjihad melalui dakwah dan diskusi (dengan menggunakan al-Qur`an sebagai argumentasi) ${ }^{17}$.

Kesebelas, dalam surat al-Hajj, kata ini ditemukan 1 (satu) kali pada ayat 78. Kata itu digunakan utuk makna kesungguhan menegakkan agama Allah dengan mengamalkan ajarannya. Arti ini ditunjukkan oleh keterkaitannya dengan penjelasan mengenai prinsip kemudahan/tidak ada kesulitan dalam melaksanakan ajaran agama. Muhamad Ali al-Says ketika memberikan interpretasi terhadap ayat ini mengungkapkan bahwa jihad itu digunakan untuk melawan setiap musuh. Adapun musuh yang dihadapi dengan jihad itu ada dua macam. Pertama musuh yang bersifat abstrak yaitu nafsu dan setan. Kedua musuh yang tampak nyata yaitu orang kafir dan munafik.

Ada ungkapan yang mendukung pengertian jihad seperti ini, "Kita baru kembali dari jihad kecil dan akan memasuki jihad besar". Ini sebenarnya perkataan Ibrahim bin Alaih, tetapi ada juga yang mengatakan itu hadis namun tidak ditemukan dalam Kitabkirab hadis yang mu'tamad. Maka al-Bani mengatakan ungkapan itu tidak apat disebut hadis. Akan tetapi banyak hadis Nabi yang mengandung makna jihad melawan setan dan hawa nafsu.

Keduabelas, dalam surat al-`Ankabut, kata jihad disebut dua kali pada ayat 6, dalam bentuk kata kerja masa lalu dan masa kini. Di sini kata itu diuntukkan kepada semua

${ }^{17} \overline{Y u s l e m, ~ N a w i r, ~ " K o n t e k s t u a l i s a s i ~ P e m a h a m a n ~}$ Hadis", Miqot: Jurnal Ilmu-ilmu Keislaman, Vol. 34, No. 1, 2010, h. 54. perbuatan saleh, karena Allah menjajikan setiap usaha saleh yang dilakukan dengan mengarahkan semua kemampuan hasilnya untuk dirinya sendiri. Pengertian jihad seperti ini sudah dijelaskan di atas menurut versi hadis.

Ketigabelas, dalam surat Luqman, disebut satu kali dalam bentuk kata kerja pada ayat 15 . Di sini kata jihad digunakan untuk arti usaha keras seorang ibu menyuruh anaknya mensyirikkan Allah. Hal ini mengindikasikan makna jihad dengan usaha keras dengan segala kemampuan dan cara agar apa yang dimaksud dapat tercapai. Ibnu Abbas berkata, Aku mendengar Rasulullah SAW bersabda, 'Barang siapa yang merasakan keletihan pada sore hari, karena pekerjaan yang dilakukan oleh kedua tangannya, maka ia dapatkan dosanya diampuni oleh Allah SWT pada sore hari tersebut." (HR. Imam Tabrani).

Keempat belas, dalam surat al-Fatbir, ditemukan 1 (satu) kali dalam bentuk kata benda yang dikaitkan dengan kata sumpah pada ayat 4. Ini menunjukkan penggunaan kata jihad untuk arti sungguh-sungguh dalam melakukan sesuatu atau mempertahankan prinsip. Aisyah ra. menceritakan: Nabi pernah ditanya: "Manakah amal yang paling dicintai Allah? Beliau bersabda: "Yang dilakukan secara terus menerus meskipun sedikit. Beliau bersabda lagi:"Dan lakukanlab amal-amal itu, sekadar kalian sanggup melakukannya." (HR. al- Bukhari).

Kelimabelas, dalam surat Mubammad, disebut satu kali dalam bentuk kata benda (pelaku) pada ayat 31 yang diturunkan setelah Nabi hijrah ke Madinah. Di sini ia dikaitkan dengan ujian untuk mengetahui siapa yang berjihad dan yang sabar. Dalam konteks ini jihad diartikan upaya keras mengendalikan diri menghadapi semua cobaan. Ibnu Umar ra. bersabda, 'Sesungguhnya Allah SW'T mencintai seorang mu'min yang bekerja dengan giat dan semangat". (HR. Imam Tabrani). 
Keenambelas, pada ayat 1 surat alMumtabinah, kata jihad ditemukan 1 (satu) kali yang dipergunakan untuk arti semua usaha sungguh-sunggu untuk mendapatkan ridha Allah. Muhammad Mushtafa al-Maraghi menerangkan bahwa kata jihad dalam ayat ini digunakan untuk arti keluar dari rumah atau kampung halaman bergerak dengan daya di jalan Allah untuk mendapatkan ridha-Nya. Anas ra. menceritakan, Rasulullah saw. bersabda: "Sesungguhnya sekali berangkat untuk jihad fy sabilillah, di waktu pagi ataupun sore itu adalah lebih baik nilainya daripada dunia dan segala isinya" (HR. Muttafaq 'alaih).

Ketujubbelas, dalam surat al-Shaf, kata itu hanya ditemukan 1 (satu) kali pada ayat 11 yang digunakan untuk arti menegakkan agama Allah dengan harta dan jiwa guna mendapatkan kemenagan di dunia dan di akhirat. Makna ini sesuai dengan sabda Rasulullah yang disampaikan oleh Anas bahwa Raslullah berdsabda: "Birjihadlah kamu di jalan Allah dengan harta, jiwa dan lidah kamu." (HR. Ahmad dan al-Nasa i)

Kedelapanbelas, dalam surat al-Tabrim, kata jihad ditemukan satu kali pada ayat 9 dalam bentuk perintah yang digunakan untuk arti berperang melawan orang kafir dan munafik.

Abu Hammad berkata: "Saya mendengar Rasulullah saw. bersabda di atas mimbarnya: "Dan persiapkan untuk memerangi kaum kafirin itu dengan segala kekuatan yang kalian dapat siapkan, ingatlah bahwasanya kekuatan ialah memanah, ingatlah sesungguhnya kekuatan ialah memanah dan ingatlah sesungguhnya kekuatan ialah memanah." (HR. Muslim).

Sampai di sini tersimpul bahwa terminologi jihad yang ditemukan dalam beberapa ayat dan hadis yang turun sebelum Rasulullah hijrah ke Madinah, digunakan untuk semua usaha yang mengerahkan segala potensi yang dimiliki untuk memperkuat eksistesi kebenaran dan melawan semua kebatilan.
Jihad dalam konteks ini dilakukan oleh Rasulullah bersama sahabat dengan berdakwah mengajak orang-orang musyrik menyembah Allah dan meninggalkan berhala. Dakwah Rasul dimulai secara tertutup dari rumah ke rumah. Kemudian setelah turun perintah kepada Nabi agar berdakwah secara terus terang (QS, 15:94), barulah dakwah dilakukan secara terbuka. Dakwa Rasulullah terkadang secara lisan, keteladanan, dan terkadang melalui doa dan perbuatan. Sejak inilah tekanan dan ancaman yang dialamatkan kepada umat Islam semakin keras. Nabi tidak pernah menghadapinya dengan cara kekerasan fisik, karena perang dengan kekerasan fisik secara terbuka belum disyariatkan di Mekkah. Beliau tidak pernah melakukan jihad dengan kontak fisik dan senjata yang berdampak kepada kematian dan kerugian materil, meskipun pada ayat-ayat tersebut banyak ditemukan perintah berjihad. Hal itu karena pada periode Mekkah jihad dalam arti perang belum disyariatkan.

Sedangkan istilah jihad pada ayat-ayat dan hadis yang turun setelah Rasul saw. hijrah ke Madinah, di samping digunakan untuk makna di atas, juga digunakan untuk makna yang lebih khusus yakni perang terbuka dengan menggunakan senjata melawan orang-orang musyrik. Setelah Nabi diperintahkan hijrah ke Madinah untuk menghindari perang terbuka yang tidak diinginkan Allah dan ternyata orangorang kafir tetap melakukan pengejaran untuk membunuh Nabi bersama pengikutnya, maka Allah pun mensyariatkan perang dalam arti qital "Perangilah di jalan Allah mereka yang memerangi kamu dan janganlah melampaui batas., karena sesunggubnya Allah tidak suka orang yang melampani batas" (QS,2:190). Sejak itu jihad boleh dilakukan dengan peperangan terbuka melawan orang kafir untuk membela diri dan agama Allah. Hukum jihad ini adalah fardu kifayah, dengan demikian jihad (perang) harus berdasarkan instruksi dan berjalan di bawah 
komando (Rasulullah) agar tidak melampau batas kemanusiaan.

Dari ayat-ayat dan hadis yang berbicara tentang jihad, diperoleh petunjuk bahwa kata jihad di dalam al-Qur'an dan hadis itu mengandung makna yang sangat luas; yakni kerja keras menegakkan kebenaran, tabah dalam menghadapi tantangan, sungguhsungguh dalam melaksanakan tugas, rela berkorban materi dan inmateri, mengendalikan diri, ujian untuk membedakan siapa yang mukmin dan siapa yang berbohong, melaksanakan amal-amal saleh, berdakwah dengan al-Qur'an dan berperang dengan senjata melawan orang kafir. Bila disimpulkan secara induksi, dapat dirumuskan bahwa terminologi jihad dalam al-Qur'an dan hadis ialah seluruh usaha optimal di jalan Allah dengan menggunakan semua potensi yang dimiliki untuk menegakkan kebenaran dan meminggirkan kebatilan. Pengertian jihad seperti ini sudah menjadi kesepakatan para ulama tafsir meskipun mereka merumuskannya dalam redaksi yang agak berbeda.

\section{Tujuan Jihad Menurut al-Qur'an dan Hadis}

Dalam Ummah, jihad dengan pengertian umum bertujuan untuk menegakkan kebenaran dan melawan kebatilan, misalnya melaksanakan ajaran agama Allah, menghancurkan kemaksiatan, kesesatan dan termasuk berijhad melawan orang $\mathrm{kafir}^{18}$. Semuanya dilakukan untuk menegakkan kalimat Allah di bumi ini. Rasulullah mengumumkan hal itu dalam sabdanya: Siapa saja yang berperang dengan tujuan menjadikan kalimat Allah menjadi yang paling tinggi, maka ia berada di jalan Allah. (HR. al-Bukhari). Dalam hadis lain Rasululllah mengumumkan: "Aku diperintabkan untuk memerangi manusia hingga mereka mengatakan La Ilaha illa Allah

${ }^{18}$ Ummah, Sun, "Akar Radikalisme Islam di Indonesia", Humanika, Vol. 12, No. 1, 2012, h. 32.
Mubammad Rasulullah (HR. al-Bukhari dan Muslim).

Akan tetapi ada di antara umat Islam itu berjihad untuk tujuan duniawi seperti dalam hadis yang dinukil oleh Abu Musa al-As'ary bahwasanya ada seorang anak pedesaan mendatangi Nabi saw, dan berkata: "Ya Rasulullah, ada seorang yang berperang dengan tujuan memproleh harta rampasan, ada pula untuk popularitas dan ada pula untuk memperlihatkan keberaniannya. Dalam riwayat lain disebutkan: "Ada orang yang berperang karena melepaskan kemarahannya, maka yang manakah di antara mereka yang termasuk bejihad fi sabilillah?" Rasulullah saw. menjawab: "Barangsiapa yang berperang dengan tujuan meninggikan agama Allah, maka dialah yang disebut jihad fi sabilillah.(HR.Muttafaq 'alaih).

Di sini dapat disimpulkan bahwa tujuan akhir dari jihad di jalan Allah adalah untuk menegakkan agama Allah di bumi ini, baik dengan melaksanakan ajarannya secara maksimal sehingga agama itu memberi pengaruh dalam perilaku keseharian umatnya. Atau menegakkan agama melalui peperangan melawan setiap orang yang ingin menghancurkan agama Islam baik dari dalam maupun dari luar.

\section{Hukum dan Etika Jihad Menurut al- Qur'an dan Hadis}

Pada dasarnya, dalam Arake, jihad untuk menegakkan kebenaran dan menghancurkan kebatilan adalah kewajiban setiap individu umat Islam sesuai dengan keahlian dan kemampuan masing-masing (QS, 3:110) ${ }^{19}$. Demikian juga jihad dalam arti khusus adalah menjadi kewajiban umat Islam untuk mempertahankan diri dan eksistensi kalimat Allah di bumi ini (QS, 2:191). Para ahli tafsir dan fikih membagi hukum jihad dari segi sifatnya kepada dua macam: Kewajiban yang

${ }^{19}$ Arake, Lukman, "Pendekatan Hukum Islam Terhadap Jihad dan Terorisme", Ulumuna, Vol. 16, No. 1, 2012, h. 189-222. 
bersifat pribadi ('ainiy) dimana setiap individu Muslim wajib melakukan jihad menegakkan kebenaran dan melawan semua kebatilan, tanpa mengenal waktu dan tempat serta tanpa harus ada komando dari pimpinan. Kewajiban ini meskipun bersifat ‘aniyah, dapat dilaksanakan secara sendiri dan secara bersama. Jihad seperti ini adalah jihad yang tidak menggunakan alat perang dan berhadapan dengan musuh Islam.

Dalam Subhan, kewajiban yang bersifat kolektif (kifayab), kewajiban ini dilakukan oleh sekelompok orang terlatih dan terampil yang dibentuk oleh penguasa. Kewajiban jihad dimaksud ialah melawan orang-orang kafir, munafik, dan orang yang murtad ${ }^{20}$. Untuk melawan musuh seperti ini dilakukan dengan perang kontak fisik. Kewajibannya bersifat kolektif ini harus dilakukan secara terorganisisr dan terkomando, artinya baru boleh dilakukan apabila sudah ada perintah dari pimpinan. Sebelum perang Hudaibiyah di mulai, Rasul menyuruh Abbas memanggil semua pasukannya. Setelah mereka berkumpul mengelilinginya, barulah Rasul memberi arahan dan komando dengan perintah "serbu! semoga Allah menolong kita”. Hal itu dilakukan Rasul agar peperangan itu tidak keluar dari ketentaun yang disyariatkan. Adapun peperangan yang dilakukan oleh seseorang untuk membunuh musuh dengan didorong oleh emosi dan dendam, tidak dapat disebut jihad yang disyariatkan.

Memahami petunjuk ayat-ayat al-Qur'an dan penjelasan dari hadis-hadis Rasulullah, disimpulkan bahwa jihad dalam arti perang memiliki ketentuan-ketentaun ketat dan tidak boleh dilakukan semena-mena berdasarkan hawa nafsu. Beberapa hal yang harus diperhatikan dalam melaksanakan jihad ialah:

Pertama, jihad dalam arti kontak senjata dilakukan sebagai upaya mempertahankan jiwa dan agama dari serangan musuh.

${ }^{20}$ Subhan, Zaitunah, Studi Bias Gender dalam Tafsir Qur'an (Yogyakarta: LKiS, 1999).
Pelaksanaanya harus secara terorganisir dan terkomandoi berdasarkan keputusan ijtihad penguasa.

Kedua, Jihad merupakan alternatif terakhir, setelah ada negosiasi untuk damai dengan mengajak mereka masuk Islam. Jika hal itu tidak berhasil maka jihad boleh dilaksanakan.

Ketiga, dalam operasionalnya jihad tidak boleh melampaui batas. Setelah tidak ada lagi perlawanan musuh maka perang harus dihentikan. Ketentuan lain tidak boleh membunuh anak-anak, wanita hamil, orang tua lanjut usia, merusak ternak dan perkebunan serta fasilitas umum yang menjadi kebutuhan masyarakat banyak. Berdasarkan ketentuan ini tidak dibenarkan menggunakan senjata pemusnah massal.

Diceritakan oleh Abdullah bin Amar ra. Dalam beberapa peperangan Nabi menemui perempuan dan anak-anak bergentayangan, lalu beliau berkata' Aku mengutuk membunuh wanita dan anak-anak ini (HR. Al-Bukhari).

Keempat, penawanan musuh tersebut dibolehkan sebagai salah satu strategi perang, meskipun dibolehkan, tetap saja tidak dibolehkan menganiaya tawanan. Rasul senang mendengar keluhan dan pemikiran tawanan perang Hudaibiyah, bahkan pernah memeluki mereka dengan kasih sayang dan kemudian membebaskannya setelah mereka menyatakan keislamannya.

Dari Sahl bin Sa'id ra, menceritakan bahwa Nabi memberi bendera Islam pada perang Khaibar untuk memimpin pasukan. Ali Berkata: Wahai nabi apakah kami perangi semua seperti dulu mereka memerangi kami. Nabi berkata: Sabarlah, jika bisa ajaklah mereka kepada agama Islam seperti yang diperintahkan Allah kepada mereka. Kalau mereka enggan tetap memusuhi kamu maka perangilah mereka (HR. Al-Bukhari). Musa al-Ay`ari berkata Nabi memerintahkan membebaskan tawanan 
perang (kafir) dan memberi makan dan menjenguk mereka (HR. Al-Bukhari).

Kelima, Ibnul Qayyim menambahkan lagi, "Di antara petunjuk Rasulullah adalah tidak menahan utusan apabila ia sudah memilih Islam. Penguasa kaum Muslimin tidak boleh menghalangi utusan tersebut untuk kembali ke kaumnya, bahkan penguasa kaum Muslimin harus mengembalikannya kepada kaum yang mengutusnya. Beliau berkata: "Aku tidak pernah melanggar janji dan menahan utusan. Kembalilah kepada mereka! Apabila yang ada di hatimu sekarang ini masih terus ada, maka kembalilah. $^{21}$

Keenam, bukan untuk balas dendam Seorang Baduwi yang bernama Dutsur/Datsur yang sudah lama berniat membunuh Rasulullah melihat Rasul tertidur secara diam-diam ia mengambil dan menghunus pedang ke arah kepala Rasul. Rasululah terbangun dan terkejut melihat Datsur sudah siap memenggal kepalanya. Datsur berkata: Hai Muhammad siapakah yang dapat menghalangi saya memenggal kepalamu? Rasulullah menjawab dengan tenang: "Allah". Mendengar nama Allah Datsur gemetar dan pedang itu jatuh dari tangannya. Rasulullah mengambilnya dan berkata: "Siapa yang dapat menghalangi pedang ini dari kepalamu hai Datsur? Ia gemetar dan pucat sambil berkata: "Tidak ada". Rasulullah dengan senyum melepaskan dia sambil berpesan agar di satu saat Datsur mengucapkan kalimah sahadat (HR.al- Baihaqi)

\section{Keutamaan Berjihad Menurut al-Qur`an dan Hadis}

Ayat-ayat yang menggunakan kata jihad dengan keberagaman bentuknya yang ditulis di atas memberi informasi bahwa jihad memiliki keutamaan-keutamaan. Di antaranya

${ }^{21}$ Ibnu Qayyim, Zâd al-Ma’âd Fi Hadyi Khairil Tbâd, Tahqîq Syu'aib al-Arnauth dan Abdil Qadir alArna uth. Jilid 3, Cet. 2 (Beirut: Dar al-Fikri,1421 H), h. 127. memperoleh kedudukan yang terhormat di sisi Allah (QS, 9:20). Dosa-dosa orang yang berjihad diampuni oleh Allah (QS, 16:110) dan orang yang berjihad memperoleh kemenangan di dunia an diakhirat (QS, 61:11).

Orang yang mati ketika perang dinyatakan mati syahid. Penghargaan tertinggi bagi yang syahid ialah seperti kata Rasul "Mereka dibangkitkan dengan darah lukanya yang harumnya bagaikan minyak kesturi dan surga tempat kembalinya "(HR. Ahmad). Jihad fi sabilillah termasuk amal yang pang disukai Asllah (HR. Muttafaq 'Alaih). Sekali berangkat untuk berperang fi sabilillah, di waktu pagi ataupun sore itu adalah lebih baik nilainya daripada dunia dan segala apa yang ada di dalamnya ini yakni dari harta benda di dunia dan seisinya ini. (HR. Muttafaq 'alaih). Perang yang wafat di medan perang ditulis sebagai syuhada yang dijanjikan masuk surga (HR. Muslim).

\section{Jihad Melalui Aksi Anarkis dan Teror}

Terminologi jihad dalam ayat-ayat alQur an dan hadis-hadis Rasulullah digunakan untuk dua pengertian. Dalam Laisa, pertama untuk makna umum yaitu menumpahkan semua kemampuan berjuang di jalan Allah untuk menegakkan kebenaran dan melawan semua kejahatan guna memperoleh ridha Allah ${ }^{22}$. Jihad menjadi kewajiban setiap individu Muslim yang pelaksanaannya sesuai dengan ketentuan syariat Islam. Kedua, digunakan untuk makna khusus yaitu mengerahkan semua kemampuan berjuang melawan musuh yang memerangi umat Islam. Dalam arti ini jihad harus berdasarkan keputusan pimpinan dan dilaksanakan secara terorganisir agar tidak keluar dari etika jihad yang disyariatkan.

Dalam Ratnasari, aksi anarkis seperti peledakan WTC di Amerika 11 September

22 Laisa, Emna, "Islam dan Radikalisme", Islamuna: Jurnal Studi Islam, Vol. 1. No. 1, 2014, h. 54. 
2001 yang mengakibatkan ribuan umat manusia tewas, bom bunuh diri di Hotel The Marriot, 2003 dan 2010 di Jakarta juga menelan banyak korban jiwa, Bom Bali I, tahun 2004 dan Bali II tahun 2005, Kedutaan besar Australia tahun 2004 dan bom nunuh diri di Bandara Internasional Domo Dedovo di Moskow di awal tahun 2011, penolakan oleh sekelompok pembela Islam, terhadap pembangunan GKI Yasmin di Bogor yang sudah terjadi sejak tahun $2002^{23}$. Bom bunuh diri di Gereja Katolik Medan. Truk maut dengan kecepatan tinggi menghantam kerumunan orang menewaskan sedikitnya 84 orang dan melukai puluhan lainnya di Nice, Perancis. Serangkaian serangan teroris dengan penembakan massal, bom bunuh diri, terjadi di Paris, Perancis. Serangan di Sarinah, Jakarta 2016, dan penembakan membabi buta di berbagai negara. Ledakan bom transportasi umum di London menewaskan 56 orang dan lebih 700 orang terluka.

Aksi-aksi anarkis seperti disebut di atas yang dilakukan oleh sekelompok komunits Islam radikal dalam melampiaskan kekesalannya terhadap Barat, khususnya Amerika dan sekutunya bukanlah bentuk jihad yang disyariatkan melalui al-Qur'an dan hadis. Jihad dilaksanakan untuk menegakkan agama Allah di bumi ini, membela kebenaran dan mempertahankan keselamatan jiwa. Jihad menurut al-Qur'an dan hadis merupakan alternatif terakhir untuk membela diri dan agama Allah, oleh karena itu jihad harus bersifat defensif tidak dengan ofensif serta tidak melampaui batas. Oleh karena itu yang boleh diperangi hanyalah orang yang

23 Azyumardi Azra, Makalah "Geneologi Islam Radikal: Dinamika dan Masa Depannya di Indonesia" dalam seminar 11 Des. 2010 di Bukittinggi, h. 24. Lihat juga Ratnasari, Dwi, "Fundamentalisme Islam", Komunika: Jurnal Dakwah dan Komunikasi, Vol. 4, No. 1, 2010, h. 4057. memerangi umat Islam untuk menghancurkan agama Allah di bumi ini. Islam dikenal dengan agama yang membawa keselamatan dan kedamaian umat manusia di dunia dan di akhirat. Ia bukan agama teroris, anarkis dan radikal yang harus ditakuti dan dimusuhi, sebagaimana yang dituduhkan yang oleh orangorang Barat. Maka jihad tersebut disyariatkan sebagai upaya menciptakan kedamaian dan keselamatan umat manusia.

\section{Penutup}

Ayat al-Qur'an dan hadis Rasulullah banyak membicarakan persoalan jihad sebagai bukti pentingnya peran jihad dalam menegakkan kebenaran di bumi ini. Jihad dalam al-Qur'an dan hadis dimaknai sebagai upaya maksimal untuk menegakkan kebenaran Allah dan menghancurkan kebatilan dan musuh-musuh Allah, baik melalui dakwah maupun perang fisik. Umat Islam diwajibkan ikut berjihad sesuai dengan kadar kemampuannya. Jihad dalam arti perang secara frontal baru disyariatkan setelah hijrah ke Madinah dan itupun harus atas perintah Rasul dan dengan etika yang sangat manusiawi. Oleh karena itu, berbagai aksi anarkis dan teror yang dilakukan sekelompok umat Islam radikal tidak dapat disebut dengan jihad fi sabilillah karena bertentangan dengan syariat Islam

\section{Daftar Pustaka}

\section{Buku Teks}

Al-Baqi, Muhammad Fuad, Abd, al-Mu jam alMufabras li Al-fazh al-Qur an (Beirut: Dar al-Fikr, 1987).

Al-Fairuzy, Muhammad Ya`qub, Majmu at alTafasir (Beirut: Matba`ah al-Amirah, Cet. I, th. $1317 \mathrm{H})$.

Al-Gazaly, Muhammad, Figh al-Sirah (Beirut: Dar al-Kutub al-Hadits, Cet. II, 1987).

Al-Maraghy, Ahmad Mushthafa, Tafsir alMaraghy (Beirut: Dar al-Fikr,t.th). 
Al-Qasimy, Muhammad Jamaluddin, Mahasin al-Ta wil (Mesir: Isa al-Babi al-Halaby, t.th).

Al-Qurthubi, Muhammad, al-Jami li Abkam alQur an (Mesir: Dar al-Fikr, 1961).

Al-Sayis, Muhammad Ali, Tafsir Ayat al-Abkam, Bag. III, (Riyadh: Dar al-Fikr, t.th).

Al-Shabuni, Muhammad Ali, Tafsir Abkam Min al-Qur'an (Mesir: Dar al-Fikr, Jilid II, t.th).

Al-Syaukany, Muhammad, Fath al-Qadir, (Mesir: Dar al-Fikr, t.th).

al-Zubaidi, Imam, Mukhtahar Shabih al-Bukhari, Terj. Oleh Drs. Cecep Samsul Hari dan Tholib Anis, dengan Judul: Ringkasan Shabih al-Mukhari (Bandung: Mizan, Cet. IV, 2000).

Hamka, Tafsir al-Az̧ar Jakarta: Pustakan Panjimas, t.th).

Ibnu Qayyim, Zâd al-Ma'âd Fi Hadyi Khairil Ibâd, Tahqîq Syu'aib al-Arnauth dan Abdil Qadir al-Arna uth. Jilid 3, Cet. 2, (Mesir: Dar al-Fikr, 1421).

Imam Aby Zakariya bin Syarf al-Nawawy, Riyadah al-Shalibin (Damaskus: Muassasah `Ulum al-Qur`an, 1990), cet. I.

Ridha, Muhammad Rasyid, Tafsir al-Qur an alKarim (tafsir al-Manar) (Mesir: Dar al-Fikr, t.th).

Salman Harun, dkk., (ed.al), Ensiklopedi alQur'an Kajian Kosa Kata dan Tafsirnya (Jakarta: Yayasan Bimantara, 1997).

Subhan, Zaitunah, "Tafsir kebencian." Studi Bias Gender dalam Tafsir Qur'an [Tafsir of Hatred. The Study of Gender Biased in the Qur'an ic Exegesis]. (Yogyakarta: LKiS, 1999).

Shihab, M. Qurais, Tafsir al-Mishbah (Jakarta: Perpustakaan Umum Islam Jama, th. 2005).

\section{Jurnal}

Abdillah, Junaidi, "Radikalisme Agama: Dekonstruksi Tafsir Ayat-ayat
"Kekerasan" dalam AlQur'an", Kalam, Vol. 8, No. 2, 2014.

Arake, Lukman, "Pendekatan Hukum Islam Terhadap Jihad dan Terorisme", Ulumuna, Vol. 16, No. 1, 2012.

Bakri, Syamsul, "Islam dan Wacana Radikalisme Agama Kontemporer", Jumal Dinika, Vol. 3, No. 1, 2004.

Ummah, Sun, "Akar Radikalisme Islam di Indonesia", Humanika, Vol. 12, No. 1, 2012.

Hanafi, Muchlis Muhammad, "Problematika Terjemahan Al-Qur'an Studi pada Beberapa Penerbitan Al-Qur'an dan Kasus Kontemporer", Subuf Jurnal Pengkajian Al-Qur'an dan Budaya, Vol. 4, No. 2, 2011.

Laisa, Emna, "Islam dan Radikalisme", Islamuna: Jurnal Studi Islam, Vol. 1, No. 1, 2014.

Mustaqim, Abdul, "Deradikalisasi Penafsiran Al-Qur'an dalam Konteks Keindonesiaan yang Multikultural", Subuf Jurnal Pengkajian Al-Qur'an dan Budaya, Vol. 6, No. 2, 2013.

Nadia, Zunly, "Akar-Akar Radikalisme Islam dalam Tafsir fi Zilal Al-Qur'an Karya Sayyid Qutb", Mukaddimah: Jurnal Studi Islam, Vol. 18, No. 2, 2012.

Ratnasari, Dwi, "Fundamentalisme Islam", Komunika: Jurnal Dakwah dan Komunikasi, Vol. 4, No. 1, 2010.

Shidiq, Ghofar, "Teori Maqashid Al-Syari'ah dalam Hukum Islam", Majalab Ilmiah Sultan Agung, 44.11.8, 2018.

Syukri, Ahmad, "Metodologi Tafsir al-Qur'an Kontemporer dalam Pemikiran Fazlur Rahman", Kontekstualita, Vol. 20, No. 1, 2005.

Taufik, Zulfan, "Humanisme dan Ambivalensi Agama: Sinergi Pluralisme dan HAM dalam Menjaga Nilai Kemanusiaan", Titik Temu: Jurnal Dialog Peradaban, Vol. 7, No. 2, 2015. 
Wartini, Atik, "Corak Penafsiran M. Quraish Shihab dalam Tafsir al-Misbah", Hunafa: Jurnal Studia Islamika, Vol. 11, No. 1, 2014.

Yuslem, Nawir, "Kontekstualisasi Pemahaman Hadis", Miqot: Jurnal Ilmu-ilmu Keislaman, Vol. 34, No. 1, 2010.

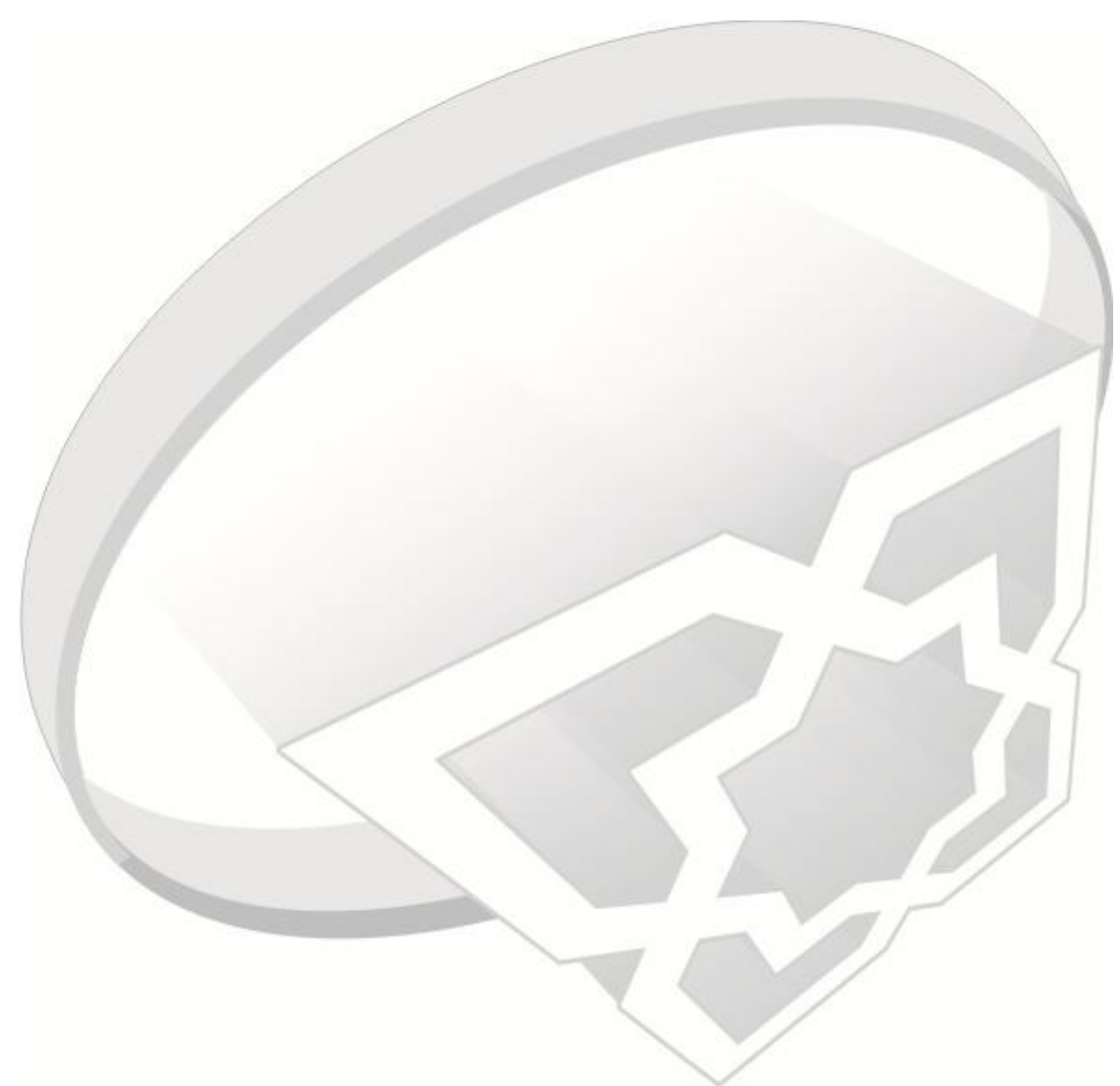

